\title{
COMBINAÇÃO DE CLAREAMENTO DENTAL INTERNO E EXTERNO À TÉCNICA DE FACETAMENTO - CASO CLÍNICO
}

Elize Tatiane Ribeiro BONAFÉ, Rodrigo Stanislawczuk GRANDE, Cristian HIGASHI, Francilene Fátima Marcondes SILVA, Osnara Maria Mongruel GOMES

Uma das principais causas de prejuízo do equilíbrio estético do sorriso é a alteração de cor. A técnica de clareamento dental representa uma opção importante no tratamento estético frente à alteração de cor dos dentes (BLANKENAU, 1999).

profissional pode lançar mão de alguns tipos de tratamento quando o dente apresentar qualquer tipo de descoloração como recuperar a estética do dente através de manobras restauradoras ou protéticas, ou ainda, associar as técnicas clareadoras às restauradoras (LIEBENBERG, 2000). A combinação de clareamento externo e interno representa um tratamento conservador para restaurar a estética de dentes não vitais manchados ou escurecidos (BARATIERI, 1995). A execução de facetas diretas através da técnica do condicionamento ácido do esmalte/dentina e do emprego de resinas compostas é uma prática que vem se tornando cada vez mais popular, essas restaurações são especialmente indicadas para os dentes anteriores que apresentam alteração de forma ou cor (ALBERS, 2002). O objetivo do presente trabalho é apresentar, através do relato de um caso clínico, as vantagens da associação de medidas mais conservadoras de reabilitação estética, tais como, o clareamento empregado interna e externamente, e o facetamento direto de dentes anteriores comprometidos por alteração de cor. 